\title{
Faecal Analysis as a Method of Describing Diets of Apes: Examples from Sympatric Gorillas and Chimpanzees at Lopé, Gabon
}

\author{
Caroline E.G. TUtin* \& Michel FERnandez Centre International de \\ Recherches Médicales de Franceville, Gasbon; Department of Biology and \\ Molecular Sciences, University of Stirling, Scotland.
}

\begin{abstract}
Faecal analysis has proven to be a useful method of studying the diets of wild apes. This is especially true for populations living in tropical forest habitat in central Africa where dense vegetation makes systematic observation of feeding difficult. The method developed and used for faecal analysis in the Lopé Reserve, Gabon, where gorillas (Gorilla g. gorilla) and chimpanzees (Pan t. troglodytes) co-occur, are described and some examples given of some of the ways in which data can be qualified and analised. Faecal analysis alone cannot give a complete picture of diet as some foods leave no recognisable remains and others, particularly vegetative plant parts, are difficult to identify taxonomically. However, standard application of the methods allow some comparisons to be made between years, species and sites.
\end{abstract}

Key Words: diet / gorilla / chimpanzee / faecal analysis / Lopé Reserve / Gabon

The diets of wild primates have been studied using a variety of methods. These fall into two main categories: Direct, i.e., those recorded by observation of the subjects ingesting foods; and indirect, i.e., those recorded from characteristic remains of foods, either left in situ or found in faeces. Direct methods are preferable as they are precise (although it is sometimes difficult, with small food items, to determine exactly what is being eaten) and give not only a qualitative lists of food items, but also quantitative data on the contribution of each item to the total diet of the study species. Indirect methods have a number of drawbacks but are sometimes the most feasible way of studying diet (Moreno-Black, 1978). This has proven to be the case for populations of gorillas and chimpanzees living in tropical forests in centralwest Africa as the apes are shy of humans and difficult to observe systematically in the dense forest vegetation.

Faecal analysis, as a technique for studying diet, has been used to supplement observations of feeding in a number of studies of wild apes. It has proven particularly useful in constructing lists of fruit foods as many seeds are swallowed whole and can be identified to species level (Kano \& Mulavwa, 1984; McGrew et al., 1988; Tutin \& Fernandez, in press a; Williamson, et al., 1990), and in documenting the frequency of insect-eating (McGrew,

*: address for correspondence: C. I. R. M. F., B. P. 769, Franceville, Gabon 
1979; Uehara, 1984; Tutin \& Fernandez, 1992). The most obvious limitation of macroscopic faecal analysis is that vegetative foods (leaves, stems and piths), flowers and soft bodied invertebrates can rarely be identified taxonomically and this results in these categories being under-represented on food lists. Microscopic identification of foliage fragments has been made in studies of the diet of some temperate mammals (e.g. Fitzgerald, 1978) but the difficulty of constructing a comprehensive reference collection of foliage samples from species-rich tropical forest sites has proven daunting (F. Maisels, pers. comm.).

So, while faecal analysis alone cannot give a complete picture of diet, it is a valuable tool for studying poorly habituated ape populations and in allowing inter-specific and inter-annual comparisons within sites. Here, we describe the methods of faecal analysis developed and used over a 9-year period at the Lopé Reserve, central Gabon, to study the diets of western lowland gorillas (Gorilla g. gorilla) and chimpanzees (Pan t. troglodytes). Examples are given of some of the ways such data can be analysed, in the hope of encouraging direct intersite comparisons of ape diet.

\section{METHODS}

Description of the Lopé study area and of general field methodology are given elsewhere with qualitative descriptions of the diets of gorillas and chimpanzees (Tutin \& Fernandez, 1992; 1993a; Williamson et al., 1990).

Fresh faecal samples found in the field were collected if they could be assigned with certainty to gorillas or to chimpanzees. The criteria used to establish the identity of the depositor were: direct (seeing or hearing the species of ape concerned), or indirect (clear footor knuckle-prints or tracking on to or back from a nesting site. It was often possible to distinguish between gorilla and chimpanzee faeces on the basis of their form and smell as the former were usually firmer in consistency and often lobed but this was not the case when gorillas had eaten large amounts of soft fruit and, if doubt remained, the faeces were not collected. Schaller (1963) found that the diameter of mountain gorilla dung allowed inference as to the age-class of the depositor. We found a similar pattern for firm gorilla faeces at Lopé though diameters were a little smaller for all age-classes: adult (silverback) males $=>6.5 \mathrm{~cm}$; adult females and adolescent (blackback) males $=4.5-6.4 \mathrm{~cm}$; juvenile $=2.0-4.4 \mathrm{~cm}$; infant $=$ $<2.0 \mathrm{~cm}$. It was rarely possible to assign chimpanzee faeces to age-classes. Faecal samples were collected whole and sealed in plastic bags and the following information noted on the bag: Date, species, age-class (if known), collection location and criteria used in species identification (post-observation, nest, trail).

Once a week, the accumulated faecal samples were weighed and then placed in metal sieves with $1 \mathrm{~mm}$ mesh (from Forestry Suppliers Inc.) and washed in running water. Once the soluble portion had gone, the seeds were sorted. Most fruit foods could be identified to species level from seeds but there are some exceptions when more that one species in the same genus have indistinguishable seeds (e.g., Uapaca spp., Psychotria spp., Ficus spp.). 
Apes at Lopé swallowed the seeds of the majority of fruit foods and only those with volumes $>4.2 \mathrm{cc}$ were systematically rejected by chimpanzees while gorillas spat out only seeds with volumes over $7 \mathrm{cc}$ (Tutin \& Fernandez, in prep.). Some fruit species with large seeds have characteristic skin that could be recognised in faeces, e.g. Pentadesma butyracea, Irvingia spp., Sacoglottis gabonensis.

Large seeds were counted and small ones ( $5 \mathrm{~mm}$ long, or less) rated on a four point abundance scale: abundant, common, few and rare. Non-fruit foods (stems, piths, leaves) are represented in faeces by undigested fragments of leaves (GLF) and by fibre. The quantities of these two categories were estimated relative to the total faecal mass and rated on the same four point abundance scale. More rarely, fragments of bark, chewed seed fragments and woody fibers were found in faeces and the amounts of these were rated in the same way.

Insects that have been eaten could usually be identified from chitinous body parts (heads, legs, wings) that are not digested. The quantity of insect remains was rated on a four point abundance scale, relative to the maximum amounts we have observed in ape faeces. At Lopé, weaver ants (Oecophylla longinoda) are the commonest prey of apes and the leafy ant nests are often ingested by gorillas. In such cases, the mature leaves pass through the gut intact and could be identified as being of monocotyledon, or dicotyledon, plant origin. Mammalian remains found in chimpanzee faeces included bones (small, intact or fragments), skin, hooves, teeth and hair and sometimes these remains could be identified to species level. Fig. 1 shows the standard form of data records used at Lopé. Other recognisable remains found occasionally in faeces included: earth, which reflects geophagy; and swollen ticks, presumable ingested during grooming. Dung beetles, dead leaves and other matter resulting from post-deposition contamination, were ignored.

We aim to collect 50 faecal samples per species per month. At Lopé, this was possible with few exceptions for gorillas but more difficult for chimpanzees.

\begin{tabular}{ll} 
N: Gorilla 217 & Evidence: Nest \\
Date: 2 May 1992 & Age-class: Silverback \\
Place: Kourou/Koumbiane & Weight: $840 \mathrm{~g}$ \\
Dialium lopense: 436 & Fibre: common \\
Diospyros dendo: 73 & GLF: rare \\
Antidesma vogeliana: few & Weaver ants: abundant \\
N Fruit Species $=\mathbf{3}$ & Foliage Score = 4 \\
N: Chimpanzee 54 & Evidence: Trail \\
Date: 11 February 1992 & Age-class: Unknown \\
Place: Azobe/Kapok & Weight: $120 \mathrm{~g}$ \\
Celtis tessmannii: 145 & GLF: common \\
Cola lizae: skin, few & Large black ants: few \\
Uvariastrum: 5 & \\
Parkia: 2 & \\
NoFruit Species $=4$ & Foliage Score $=\mathbf{3}$ \\
\hline
\end{tabular}

Fig. 1. Two examples of data recorded from faecal analysis at Lopé, Gabon. 
I.
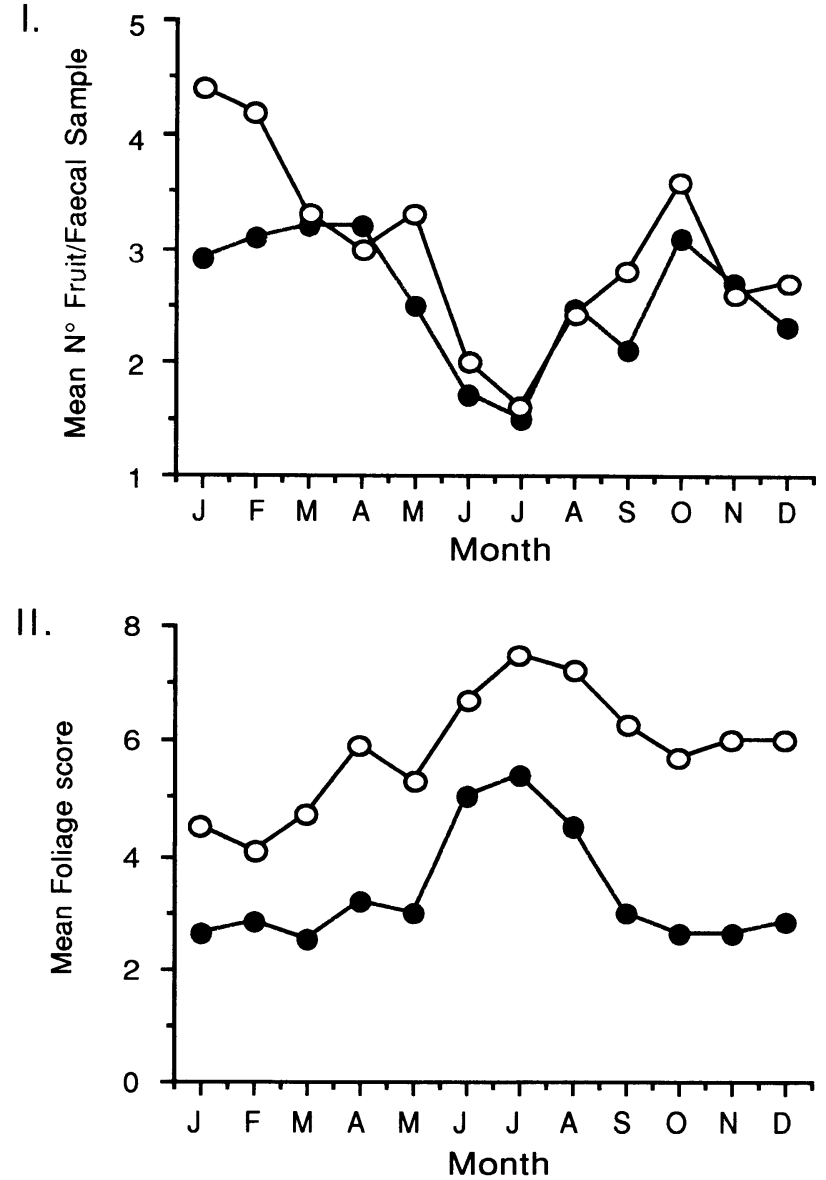

Fig. 2. Seasonal changes in diets of gorillas $(\bigcirc)$ and chimpanzees (O) at Lopé in Gabon, data

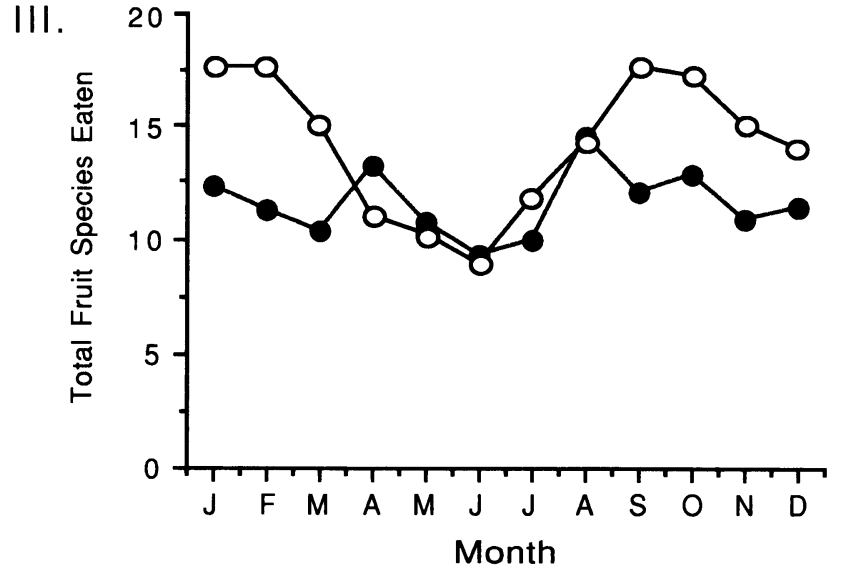
from four consecutive years, 1987-1990:

I. Monthly averages of the number of different fruit species found per faecal sample.

II. Monthly means of foliage scores derived from faecal samples (see text).

III. Monthly means of the total number of different fruit species found in faeces per month.

\section{TREATMENT OF DATA FROM FAECAL ANALYSIS}

For each faecal sample, the following indices can be established, see Fig. 1:

1. The number of different fruit species, represented by seeds and/or skin, present.

2. The Foliage Score, which was derived post hoc by assigning numerical values to the 
abundance ratings of the non-fruit plant foods as follows: abundant $=4$; common $=3$; few $=2$; rare $=1$. These scores were summed to give a single score for each sample.

At the end of each month, the following analyses can be made for each species of ape: Total number of fruit species eaten during the month; mean number of different fruit species per sample; mean foliage score; percentage of faeces containing insect, and mammalian, remains. This allows description of the diet and quantification of seasonal, inter-annual and inter-specific differences in diet.

Chimpanzees and gorillas at Lopé have similarly diverse fruit diets eating the pulp of at least 111 and 97 species respectively. Of these, 79 are eaten by both species of ape, showing a high level of dietary overlap (Tutin \& Fernandez, 1993a; Williamson et al., 1990). While gorillas at Lopé are the most frugivorous population of the species studied to date, they do eat vegetative foods (stems and leaves) more regularly and in greater quantities than do the sympatric chimpanzees (Tutin \& Fernandez, 1993a; Tutin et al., 1991a). The diets of both apes show marked seasonal changes reflecting differences in the availability of ripe fruit which becomes rare every year during the long dry season. Fig. 2 shows patterns of seasonal variation in ape diet derived from faecal analysis.

Phenological data collected monthly on 10 individuals of 60 species of tree that produce fruit eaten by apes at Lopé, show great inter-annual variation in fruit availability. Most of the monitored species ( 55 of 60 ) produce fruit seasonally, that is at the same time of year but not necessarily every year. Climate, particularly, temperature has been shown to influence flowering and fruiting rhythms of some tree species at Lopé (Tutin \& Fernandez, 1993b) but endogenous rhythms also play a part. The amount and diversity of fruit available to gorillas and chimpanzees influences not only diet but also ranging patterns. Data from faecal analysis allow accurate inter-annual comparisons in terms of the ratio of foliage to fruit consumed and diversity of the fruit diet. A comparison of mean foliage scores from gorilla and chimpanzee

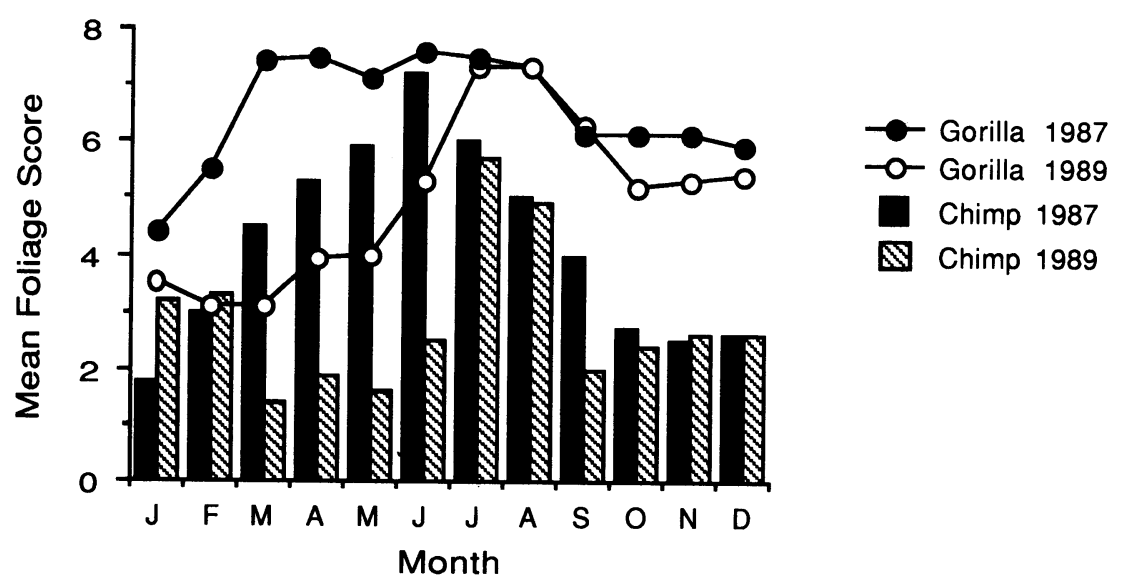

Fig. 3. Comparison of mean monthly foliage scores of gorillas and chimpanzees at Lopé in 'good' and 'bad' fruiting years (see text). Gorillas, good fruit year $(\bigcirc)$ and bad fruit year $(O)$; chimpanzees, good fruit year $(\square)$ and bad fruit year $(\square)$. 
faeces in a 'good' fruit year, 1989, and a 'bad' fruit year, 1987, is shown in Fig. 3 (see also Tutin et al., 1991a). During five months of 1987 (February-June) when less than half the number of species that had fruited in 1989 bore fruit, the average foliage scores for chimpanzees were equal to, or higher than, those of gorillas during the same months of the good fruit year, 1989. Periods of fruit scarcity at Lopé occur during the dry season that lasts 2-3 months each year and for up to 8 months in years of poor fruiting. When fruit is scarce, both gorillas and chimpanzees eat more vegetative foods (stems and leaves) but a few fruit species that are available year-round are eaten in larger quantities: the fibrous pulp and seeds of Duboscia macrocarpa are eaten by both apes and the fruit of oil palms Elaeis guineensis, by chimpanzees (Rogers et al., 1988; Tutin et al., 1991a). In poor fruit years, both gorillas and chimpanzees eat large numbers of wind- or mechanically-dispersed seeds that are available each year but normally ignored, probably because of the lengthy harvesting and processing of these foods.

However, in general, seeds of fruit foods are swallowed and pass through the gut intact. The large number of intact seeds found in gorilla and chimpanzee faeces led us to investigate their roles as seed dispersers. A preliminary study of Cola lizae, showed that gorillas are the major disperser of the large seeds $(2.5$ by $3.5 \mathrm{~cm})$ of this tree. In a good fruiting year, gorillas leave 8-11,000 seeds per sq. $\mathrm{km}$ deposited in faeces in the study area at Lopé (Tutin et al, 1991b).

\section{CONCLUSIONS}

The major limitation of faecal analysis as a method of studying diet is the bias introduced against food classes that leave no recognisable remains. These include plant parts that are completely digested: leaf and flower buds, flowers and the young leaves of some species; and soft-bodied invertebrates such as larvae, grubs and caterpillars. In addition, leaves, pith from stems and woody fibre from bast, leave remains that can rarely be identified to species level and this leads to an underestimation of the diversity of these foods in the diet. Most fruit foods do leave recognisable remains, particularly seeds and the same is true of insects with chitinous bodies such as ants and bees.

Thus, a bias towards fruit foods is likely in a food list constructed uniquely from faecal analysis. However, if combined with observation and trail evidence, over a period of several years, the bias will be much reduced. For example, Williamson et al. (1990) listed 182 plant foods of lowland gorillas at Lopé identified between 1984-89 and of these, 44\% (81) leave no identifiable (to species-level) remains in faeces. Of 31 additional foods identified from 198991 when observation of gorillas was more regular, a similar proportion (48\%) were leaves, stems, bark and flowers that leave no specifically recognisable traces in faeces (Tutin \& Fernandez, 1993 a). This does not mean that a bias in the food list for Lopé gorillas does not exist, but suggests that missed foods are likely to be eaten infrequently, or in small amounts.

Foods recorded from faecal analysis vary between years. Some of this variation is due to 
fluctuations in the availability of fruit but in some cases, sampling can introduce a bias. Ideally, the same number of faecal samples should be collected each week but this is rarely possible at Lopé as both gorillas and chimpanzees show frequent range shifts making them difficult to locate, at times for periods of several weeks. The fruit of some species of trees ripen with tight synchrony and are available for a very limited time, e.g., Ganophyllum giganteum, Gambeya spp., Ficus spp. If faecal samples are not collected continuously, these briefly available fruits can be missed. This is particularly a problem in studies of short duration, or for foods from extremely rare plant species.

However, much can be learned from faecal analysis especially for large bodied primates such as apes as they swallow so many seeds. There can be no doubt that it is an invaluable tool in studying the diet of apes in the tropical forests of central Africa where visibility is limited, particularly at ground level, and where fruit figures prominently in their diets. The foliage score, derived from faecal analysis allows seasonal, inter-annual and inter-specific differences in the ratio of fruit to vegetative foods in the diet to be quantified.

Faecal analysis is a reliable way of quantifying the frequency of insect consumption and of providing information on rare events such as geophagy, and feeding on mammals by chimpanzees. Small quantities of fresh faeces can be taken from collected samples and preserved for studies of intestinal parasites (e.g., File et al., 1976; Goussard et al., 1983).

The kinds of data illustrated in Fig. 2 and 3 provide possibilities for inter-site comparisons of the diets within and between lowland gorillas, chimpanzees and bonobos in tropical rain forest habitats.

The methods described above, applied to approximately 100 faecal samples per month require about 28-30 person-hours per month for sieving and data processing. A more refined method has been developed to study the importance of vegetative foods in the diets of chimpanzees and bonobos, involving the separation and weighing of the fibre and GLF portions of each faecal sample (Malenky \& Wrangham, 1992). This method provides more objective data than the foliage score and is particularly valuable for inter-site comparisons. The drawback is the additional time involved, particularly for large gorilla faeces but it would be of great interest to extend the use of the Malenky \& Wrangham method to more study sites. Similarly, microscopic examination of GLF would allow quantification of the relative contribution of different leaf species to the diet.

ACKNOWLEDGEMENTS We thank the L.S.B. Leakey Foundation, the World Wide Fund for Nature (Project 3254), the World Society for the Protection of Animals and especially the Centre International de Recherches Médicales de Franceville for supporting this research; Messieurs Alphonse Mackanga and Joseph Maroga-Mbina and the Direction de la Faune for their assistance in the Lopé Reserve. We thank W.C. McGrew for his in-put on developing methods of faecal analysis and many researchers at Lopé for their many hours of sieving and are grateful to Richard J. Parnell for constructive comments on the manuscript. 


\section{REFERENCES}

File, S. K., McGrew, W. C. \& Tutin, C. E. G. 1976. The intestinal parasites of a community of feral chimpanzees, Pan troglodytes schweinfurthii. J. Parasitology 62: 259-261.

Fitzgerald, A. 1978. Aspects of the food and nutrition of the brush-tailed opossum, Trichosurus vulpecula (Kerr 1792), Marsupilia: Phalangeridae in New Zealand. In: Montgomery, G. G. (ed.), The Ecology of Arboreal Folivores, 289-304. Smithsonian Institution Press, Washington, D.C.

Goussard, B., Collet, J. Y., Garin, Y., Tutin, C. E. G. \& Fernandez, M. 1983. The intestinal entodiniomorph ciliates of wild lowland gorillas (Gorilla gorilla gorilla) in Gabon, West Africa. J. Medical Primatol. 12: 239-249.

Kano, T. \& Mulavwa, M. 1984. Feeding ecology of the pygmy chimpanzees (Pan paniscus) of Wamba. In: Susman, R. L. (ed.), The Pygmy Chimpanzee: Evolutionary Biology and Behavior, 233-274. Plenum Press, New York.

Malenky, R. \& Wrangham, R. W. 1992. The relative importance of terrestrial herbs for bonobos and chimpanzees: Comparative data from Lomako and Kibale. Bull. Chicago Acad. Sci. 15: 7.

McGrew, W. C. 1979. Evolutionary implications of sex differences in chimpanzee predation and tool-use. In: Hamburg, D. A. \& McCown, E. R. (eds.), The Great Apes, 440-463. Benjamin/Cummings, Menlo Park.

- Baldwin, P. J. \& Tutin, C. E. G. 1988. Diet of wild chimpanzees (Pan troglodytes verus) at Mt. Assirik, Senegal. Amer. J. Primatol. 16: 213-226.

Moreno-Black, G. 1978. The use of scat samples in primate diet analysis. Primates 19: 215221.

Rogers, M. E., Williamson, E. A., Tutin, C. E. G. \& Fernandez, M. 1988. Effects of the dry season on gorilla diet in Gabon. Primate Report 22: 25-33.

Schaller, G. B. 1963. The Mountain Gorilla: Ecology and Behavior. Chicago University Press, Chicago.

Tutin, C. E. G. \& Fernandez, M. 1992. Insect-eating by sympatric lowland gorillas (Gorilla $g$. gorilla) and chimpanzees (Pan t. troglodytes) in the Lopé Reserve, Gabon. Amer J. Primatol. 28: 29-40.

- \& 1993a. Composition of the diet of chimpanzees and comparisons with that of sympatric lowland gorillas in the Lopé Reserve, Gabon. Amer. J. Primatol. 30: 195-211.

\& $1993 \mathrm{~b}$. Relationships between minimum temperature and fruit production in some tropical forest trees in Gabon. J. Tropical Ecology 9: 241-248.

$\longrightarrow,-$ Rogers, M. E., Williamson, E. A. \& McGrew, W. C. 1991a. Foraging profiles of sympatric lowland gorillas and chimpanzees in the Lopé Reserve Gabon. Phil. Trans. R. Soc. Lond. B. 334 (1270): 179-186.

- Williamson, E. A., Rogers M. E. \& Fernandez, M. 1991b. A case study of a plantanimal interaction: Cola lizae and lowland gorillas in the Lopé Reserve, Gabon. $J$. 
Tropical Ecology 7: 181-199.

Uehara, S. 1984. Sex differences in feeding on Camponotus ants among wild chimpanzees in the Mahame Mountains, Tanzania. Int. J. Primatol. 5: 389.

Williamson, E. A., Tutin, C. E. G., Rogers, M. E. \& Fernandez, M. 1990. Composition of the diet of lowland gorillas at Lopé in Gabon. Amer. J. Primatol. 21: 265-277.

C. G. TUTIN, M. FERNANDEZ 類人猿の食物の記述法としての䔬分析：ガボン、ロペ保護 区の同所的ゴリラとチンパンジーでの例

糞分析は野生の類人猿の食性を研究するうえで有用な方法であることが証明されてきた。特に, 採食行動のシステマティックな観察が困難な中央アフリカの密生した森林環境では，その有用性 は著しい。ここでは, ゴリラとチンパンジーが同所的に生息するガボンのロペ保護区でで発達さ せて使用している翼分析の方法と，データを数量化し分析するいくつかの方法の例を記述する。 䔬中にそれとわかる残存物ができない食物があることや，とりわけ葉や芽などの繊維性食物の種 を粪から同定することが困難であるために, 糞分析単独では食性を完全に明らかにすることはで きない。しかし, 標準化した方法で䔬分析することによって, 類人猿の食性の年間比較, 種間比 較，調査地間比較を可能にできる。 